\title{
Evaluation of the Predacious Mite Phytoseiulus Persimilis Athias-Henriot to Control Tetranychus urticae Koch on Eggplant in Sohag Govemorate
}

\author{
SAFAA M. ABDEL-AZIZ \\ Plant Protec. Res. Inst., Agric. Res. Center, Dokki, Giza, Lgypt.
}

\begin{abstract}
The predatory mite Phytoseiulus persimilis (A.H.) was released on eggplants infested with the two spotted spider mite Tetranychus urticae Koch using three different rates $(2,4$ and 6 individuals/ plant) in order to evaluate its effect in reducing numbers of the pest. The predator release decreased numbers of the pest compared with control. Six individuals/ plant enhanced the highest reduction $(90.44$ and $91.47 \%$ ) in both seasons, respectively while the lowest was two individuals/plant ( 85.16 and $86.58 \%$ ), table (3). The highest number of predator per leaf was recorded in six individuals/ plant plots; while the lowest was obtained in the control plots. The population density of the predator and its prey was discussed.
\end{abstract}

Key words: Different rates; Phytoseiulus Persimilis A-H; Tetranychus urticae.

\section{INTRODUCTION}

In Egypt, eggplant, Solanum melongena L. is one of the most important vegetable crops; while $T$. urticae Koch is one of the harmful pests limiting its production. This forced the grower to unwisely use acaricides, which caused bad affects on natural enemies, environment and human health.

Boom et al. (2002) studied the attraction of $P$. persimilis to T. urticae. The biological control of $T$. urticae using P. persimilis (Acari: Phytoseiidae) was studied in many parts of the world, in Nertherlands by Ramakers (1987), in Canada by Noubar et al. (2002) and in Bangladesh by Naher and Haque (2007). In Egypt, few authors discussed release of the predatory mite $P$. persimilis as successful method of control pest, Fawzy et al. (2006) and Abdel-Wahed et al. (2009).

Using predators as control method of T. urticae still has little attention in Egypt, so this study aimed to determine the effect of $P$. persimilis release in controlling T. urticae infested eggplants in Sohag governorate.

\section{MATERIALS AND METHODS}

\section{Experimental design:}

A field experiment was carried out to determine the effect of $P$. persimilis on $T$. urticae infesting eggplant in Shandaweel Agricultural Research Station, Sohag governorate during two successive seasons (2011 and 2012). The experiment was carried out in complete randomized block design, replicated 3 times. Each plot was consisted of 3 rows of $3.5 \mathrm{~m}$. long and $70 \mathrm{~cm}$ apart. Eggplant seedlings (cultivar Balady) were transplanted on $9^{\text {th }}$ March in two seasons.
Mass rearing and predator rele ase:

$P$. persimilis was reared on T. urticae maintained on potted bean plants in the laboratory.

Three release rates were used, 2, 4 and 6 individuals per plant in addition to the control. Predator was released on March $16^{\text {th }}$. Samples of 10 eggplant leaves were taken randomly from each plot and transferred to the laboratory for examination of $P$. persimilis and T. urticae. Samples started from 16 March to the end of the season on June $29^{\text {th }}$ at two weeks intervals. The normally recommended agricultural practices were followed.

\section{RESULTS AND DISCUSSION}

\section{Tetranychus urticae:}

Table (1) showed the mean number of T. urticae in the two seasons (2011 and 2012 seasons). Following the initial release of 2, 4 and 6 predators on March th 16, the population of the prey decreased from 26.0 to 16.3 , from 23.0 to 7.7 and from 24.0 to 5.0 individuals/ eggplant leaf after two weeks, for the predator three rates, respectively, in 2011 season. The mean number of $T$. urticae decreased rapidly to 5.7, 1.0 and 0.3 individuals/ eggplant leaf after 10 weeks, respectively before nil at the end of season. The same trend of population density was obtained in 2012; prey numbers decreased from 37.3 to 28.0 , from 36.3 to 16.3 and from 36.7 to 9.7 individuals/eggplant leaf after two weeks from predator release in the three rates, respectively, then the number decreased gradually to disappear completely. In the control treatment (without predator release), the spider mite started with 22.0 and 32.7 individuals/ eggplant leaf on $16^{\text {th }}$ of March in 2011 land 2012 seasons, respectively, the number increased to reach 221.7 and 273.3 individuals/ leaf at the end of 2011 and 2012 seasons, respectively. 
Table (1): The mean number of T. urticae per eggplant leaf at Sohag governorate, 2011 and 2012 seasons

\begin{tabular}{ccccccccc}
\hline \multirow{2}{*}{ Samp. date } & \multicolumn{9}{c}{ 2011 season } & \multicolumn{3}{c}{ 2012 season } \\
\cline { 2 - 10 } & 2 Indiv.plant & 4 Indiv./plant & 6 Indiv./plant & Cont. & 2 Indiv./plant & 4 Indiv.plant & 6 Indiv./plant & Cont. \\
\hline 16/ March & 26.0 & 23.0 & 24.0 & 22.0 & 37.3 & 36.3 & 36.7 & 32.7 \\
\hline 31/ March & 16.3 & 7.7 & 5.0 & 49.0 & 28.0 & 16.3 & 9.7 & 55.7 \\
\hline 15/ April & 12.7 & 5.3 & 3.7 & 68.0 & 21.0 & 10.0 & 6.7 & 73.3 \\
\hline 30/ April & 11.0 & 5.0 & 1.3 & 100.7 & 17.7 & 8.0 & 3.7 & 131.0 \\
\hline 15/ May & 9.3 & 3.7 & 0.7 & 153.0 & 14.7 & 5.7 & 2.3 & 162.7 \\
\hline 30/ May & 8.3 & 1.7 & 0.7 & 170.3 & 12.3 & 4.3 & 1.0 & 192.7 \\
\hline 14/ June & 5.7 & 1.0 & 0.3 & 190.3 & 5.7 & 1.7 & 0.7 & 251.3 \\
\hline 29/ June & 0.0 & 0.0 & 0.0 & 221.7 & 2.0 & 0.0 & 0.0 & 273.3 \\
\hline Mean & 9.05 & 3.48 & 1.67 & 136.14 & 14.48 & 6.57 & 3.43 & 162.86 \\
\hline
\end{tabular}

LSD $\%$ for 2011 season: $2.82 \quad$ LSD $\%$ for 2012 season: 7.88

Table (2): The mean number of $P$. persimilis per eggplant leaf at Sohag governorate, 2011 and 2012 seasons

\begin{tabular}{ccccccccc}
\hline $\begin{array}{c}\text { Samp. } \\
\text { date }\end{array}$ & \multicolumn{4}{c}{ 2011 season } & \multicolumn{5}{c}{ 2012 season } \\
\cline { 2 - 10 } & 2 Indiv./plant & 4 Indiv./plant & 6 Indiv./plant & Cont. & 2 Indiv/ plant 4 Indiv/ plant & 6 Indiv./ plant & Cont. \\
\hline 16/ March & 0.0 & 0.0 & 0.0 & 0.0 & 0.0 & 0.0 & 0.0 & 0.0 \\
\hline 31/ March & 1.0 & 1.0 & 3.7 & 0.3 & 3.0 & 4.7 & 6.7 & 0.0 \\
\hline 15/ April & 4.0 & 6.0 & 4.0 & 1.3 & 5.3 & 8.7 & 12.7 & 0.7 \\
\hline 30/ April & 8.0 & 10.7 & 14.3 & 1.3 & 8.7 & 13.3 & 20.0 & 1.3 \\
\hline 15/ May & 9.7 & 11.0 & 17.0 & 1.7 & 13.0 & 13.0 & 21.3 & 1.7 \\
\hline 30/ May & 14.3 & 19.0 & 16.7 & 1.0 & 18.0 & 20.7 & 22.7 & 2.3 \\
\hline 14/ June & 3.3 & 3.0 & 1.3 & 2.0 & 7.0 & 10.7 & 13.0 & 3.3 \\
\hline 29/ June & 0.7 & 1.0 & 0.3 & 2.0 & 1.3 & 2.0 & 4.3 & 3.7 \\
\hline Mean & 5.86 & 7.38 & 8.19 & 1.38 & 8.05 & 10.43 & 14.38 & 1.86 \\
\hline
\end{tabular}

LSD $\%$ for 2011 season: $1.39 \quad$ LSD $_{5} \%$ for 2012 season: 2.02

able (3): The effect of P. persimilis releasing on T. urticae on eggplant at Sohag governorate, 2011 and 2012 seasons

\begin{tabular}{rllllll}
\hline $\begin{array}{r}\text { Samp. } \\
\text { Date }\end{array}$ & 2011 season & \multicolumn{3}{l}{ 2012 season } \\
\cline { 2 - 7 } 2 Indiv/plant & 4 Indiv/ plant & 6 Indiv./ plant & 2 Indiv./plant & 4 Indiv./plant & 6 Indiv./plant \\
\hline 16/ March & ---- & ---- & ---- & ---- & ---- & --- \\
\hline 31/ March & $71.8 \%$ & $85.0 \%$ & $90.6 \%$ & $70.4 \%$ & $82.2 \%$ & $89.6 \%$ \\
\hline 15/ April & $74.9 \%$ & $77.5 \%$ & $76.3 \%$ & $77.5 \%$ & $81.6 \%$ & $79.3 \%$ \\
\hline 30/ April & $81.0 \%$ & $79.5 \%$ & $92.1 \%$ & $85.9 \%$ & $86.6 \%$ & $90.8 \%$ \\
\hline 15/ May & $87.8 \%$ & $89.5 \%$ & $92.8 \%$ & $88.8 \%$ & $90.4 \%$ & $91.4 \%$ \\
\hline 30/ May & $88.5 \%$ & $94.1 \%$ & $87.1 \%$ & $90.4 \%$ & $91.3 \%$ & $95.1 \%$ \\
\hline 14/ June & 92.1 & 93.1 & 94.2 & $96.0 \%$ & $96.6 \%$ & $94.2 \%$ \\
\hline 29/ June & $100.0 \%$ & $100.0 \%$ & $100.0 \%$ & $97.2 \%$ & $100.0 \%$ & $100.0 \%$ \\
\hline Mean & $85.16 \%$ & $88.38 \%$ & $90.44 \%$ & $86.58 \%$ & $89.82 \%$ & $91.47 \%$ \\
\hline
\end{tabular}

The statistical analysis indicated that the mean number of spider mites per eggplant leaf reduced significantly in the three releasing rates compared with the control in both seasons. Two individuals treatment recorded the highest number of the pest (9.05 and 14.48 individuals/ eggplant leaf) in 2011 and 2012 seasons, respectively, however, the lowest numbers (1.67 and 3.43 individuals/ eggplant leaf) were recorded in six individuals treatment in both seasons, respectively. Also the above data showed no significant differences occurred between four and six individuals treatments in both seasons.
In accordance with these results, Mowafi (2005) reported that reduction of $T$. urticae population in the early release reached $63 \%$ after 4 weeks from the $P$. macropilis (Banks) release on cucumber in greenhouse, and then increased to reach $100 \%$ after about 8 weeks. Also Shaabo et al. (2008) mentioned that the efficiency of $P$. persimilis reached $78.48 \%$ after 6 weeks from introducing the predator reaching $99 \%$ on the twelfth week.

\section{Phytoseiulus persimilis:}

The population density of $P$. persimilis predator in relation of number releasing 2011 and 
2012 seasons was summarized in Table 2. The predator started to appear with low numbers in IM(). four and six individuals treatments and the control by $1.0,1.0,3.7$ and 0.3 individuals/ eggplant leaf. respectively, on 31 March (season 2011), the number then increased gradually to reach its maximum number on 30 May for two and four individuals treatments by 14.3 and 19.0 individuals/ eggplant leaf, respectively, and on 15 May for six individuals treatment by 17.0 individuals/ eggplant leaf. Mean while, predator number maximized at the end of the first season in control treatment. After that, the numbers decreased until the end of season. In the second season (2012), similar rend was obtained as predator recorded on 31 March 3.0, 4.7 and 6.7 for two, four and six individuals treatments, respectively. The numbers maximized in May 30 by 18.0, 20.7 and 22.7 individuals/ eggplant leaf for the previous treatments, respectively. In control the predator recorded on April 15 then, increased gradually till the end of 2012 season.

Consequently, the differences between the treatments were significant in both seasons. Six individuals treatment had the highest mean number of predator with no significant difference with four individuals treatment; while control treatment had significantly the lowest mean number of predator in 2011 season. Also, similar results were obtained in 2012 season, except that the difference between four and six individuals was not significant.

Concerning the effect of releasing of $P$. persimilis on the population of its prey T. urticae, data in Table (3) revealed that the three rates of release reduced prey number with $71.8,85.0$ and $90.6 \%$, respectively in 2011 season, and with $70.4,82.2$ and $89.6 \%$, respectively in 2012. The reducing rates increased to reach $100 \%$ at the end of two seasons for all treatments, except two individuals treatment in 2012 season. These results agreed with that of Abdel-Wahed et al. (2009).

As shown in Table (3), two, four and six individua ls treatments reduced the prey numbers with means $85.16,88.38$ and $90.44 \%$, respectively, in 2011 season, and with 86.58, 89.82 and $91.47 \%$, respectively, in 2012 season.

\section{REFERENCES}

Abdel-Wahed, N. M.; El-Sayed, K. M. and Mona, S. Et-Ghobashi. 2009. Biological control of Tetranychus unticue Koch on watermelon in open field and greenhouse by using the predatory mite species Phtoseiulus persimilis (A. - H.). Journal of Agricultural Research, 87 (4): 1057-1062.

Boom. C. E. M.; Beek, T. A. and Dicke, M. 2002. Attraction of Phytoseiulus persimilis (Acari: Phytoseiidae) towards volatiles from various Tetranychus urticae infested plant species. Bulletin of Entomological Research, 92: 539-546.

Fawzy, M. M. H.; El- Sayed, K. M. and El-Erksousy, M. H. 2006. Evaluation of the predaceous mite Phytoseiulus persimilis (A.-H.) release on peach and almond trees at north Sinai governorate to control the two spotted spider mite Tetranychus urticae Koch. Journal of Agricultural Research, 84(6): 1811-1817.

Mofleh, M.; Ahmed, M. and Haloum, M. 2008. The predation efficiency of Phytoseiulus persimilis Athias-Henriot on Tetranychus urticae (Koch) under laboratory conditions. Arab J. Pl. Prot., 26: 143-147.

Mowafi, M. H. 2005. Release of the predacious mite, Phytoseiulus macropilis (Banks) to control Tetranychus urticae Koch (Acari: Phytoseiidae \& Tetranychidae) in a cucumber greenhouse. Egyptian Journal of Biological Pest Control, 15(2): 109-111.

Naher, L. and Haque, M. 2007. Biological control of Tetranychus urticae (Acari: Tetranychidae) using Phytoseiulus persimilis (Acari: Phytoseiidae). Research Journal of Agriculture and Biological Sciences, 3(6): 550-553.

Noubar, J.; Haque, T. and Jacques, L. 2003. Management of two-spotted spider mite, Tetranychus urticae (Acari: Tetranychidae) in eggplant fields. Phytoprotection, 84: 1-8.

Ramakers, P. M. J. 1987. Control of spider mites and thrips with phytoesiid predators on sweet pepper. Bulletin-SROP, 10(2): 158-159.

Saabo, A.; Halloum, M. and Zidan, R. 2008. Efficiency of the predatory mite Phytoseiulus persimilis Athias-Henriot in controlling Tetranychus urticae (Koch) on strawberry. Arab J. P1. Prot., 26: 58-61. 